\title{
TMC-49A, a Novel Transcriptional Up-Regulator of Low Density Lipoprotein Receptor, Produced by Streptomyces sp. AS1345
}

\author{
Yutaka Koguchi, Yasuyuki Asai, Shin-ichi Suzuki, Maki Nishio, Noriyuki Yanaka ${ }^{\dagger}$, \\ Kenji OMORI ${ }^{\dagger}$, Tetsuo OHNUKI* and Saburo Komatsubara \\ Lead Generation Research Laboratory at Toda and ${ }^{\dagger}$ Lead Generation Research Laboratory at Kashima, \\ Tanabe Seiyaku Co., Ltd., \\ 2-50 Kawagishi-2-chome, Toda-shi, Saitama 335, Japan \\ † 16-89 Kashima-3-chome, Yodogawa-ku, Osaka 532, Japan
}

(Received for publication October 14, 1997)

\begin{abstract}
Microbial metabolites were screened for a transcriptional up-regulator of low density lipoprotein (LDL) receptor by a reporter assay. TMC-49A was discovered as an up-regulator obtained from the fermentation broth of Streptomyces sp. AS1345. The structure of TMC-49A was elucidated to be butyl $N$-phenethylcarbamate by spectroscopic analyses. This compound enhanced the synthesis of LDL receptor in human hepatoma HepG2 cells as assessed by a receptor binding assay. Taxonomy of the producing strain is also described.
\end{abstract}

Low density lipoprotein (LDL) receptor mediates the uptake of plasma LDL, a cholesterol rich lipoprotein, to supply cholesterol to cells ${ }^{1}$. When cellular demands for cholesterol are high, LDL receptor is actively synthesized to satisfy their demands via the uptake of plasma cholesterol. In contrast, when sterols accumulate within cells, the synthesis of LDL receptor is suppressed. This sterol negative feedback regulation is exerted to a large extent at the level of gene transcription by the specific transcriptional factors, SREBP-1 and SREBP-2,3).

The inhibition of cholesterol biosynthesis depletes the cellular cholesterol and activates the transcription of LDL receptor gene, thereby lowering the plasma cholesterol level. This is a plausible mechanism of HMG-CoA reductase inhibitors used clinically for ameliorating an elevated level of plasma cholesterol ${ }^{4)}$. Thus, agents that activate directly the transcription of LDL receptor gene might be another candidate for development of drugs to treat hypercholesterolemia. As a result of screening ca. 10,000 microbial extracts, we found a novel compound named TMC-49A and two known compounds, trichostatin $\mathrm{A}^{5)}$ and herboxidiene ${ }^{6}$, to up-regulate the transcription of LDL receptor. In the previous paper ${ }^{7)}$, we reported the biological properties of trichostatin A and herboxidiene. In this paper, we describe the taxonomy of the producing strain and isolation, structure elucidation, and biological properties of TMC-49A.

\section{Results \\ Taxonomy}

The producing strain AS1345 was isolated from a soil sample collected in Kanagawa Prefecture, Japan. The cultural characteristics of the strain AS1345 are summarized in Table 1.

The substrate mycelium developed well and branched irregularly. Each spore chain, which was spiral type, had more than 30 spores per chain. The spores were cylindrical or ellipsoidal, with size of $0.4 \sim 0.6 \times 0.8 \sim 1.1 \mu \mathrm{m}$, and their surface was spiny (Fig. 1). Fragmentation of substrate mycelium, sporangia, or motile spore was not observed.

The physiological properties and the utilization of carbon sources are summarized in Table 2. Analysis of the whole-cell hydrolyzate of the strain showed the presence of LL-diaminopimelic acid. On the basis of these morphological and chemical characteristics, strain AS1345 was assignable to the genus Streptomyces.

\section{Production}

Streptomyces sp. AS1345 was inoculated into a 500-ml Erlenmeyer flask containing $70 \mathrm{ml}$ of a seed medium composed of $0.5 \%$ glucose, $1.0 \%$ starch, $0.5 \%$ glycerol, 
Table 1. Cultural characteristics of strain AS1345.

\begin{tabular}{|c|c|c|c|c|}
\hline Media & Growth & Aerial mycelium & Reverse side color & $\begin{array}{l}\text { Soluble } \\
\text { pigment }\end{array}$ \\
\hline $\begin{array}{l}\text { Yeast extract - malt extract } \\
\text { agar (ISP No. 2) }\end{array}$ & Good & $\begin{array}{l}\text { Abundant, Pale blue purple } \\
\left(18-18-3^{*}\right)\end{array}$ & Yellowish brown (17-16-3) & None \\
\hline Oatmeal agar (ISP No. 3) & Good & $\begin{array}{l}\text { Abundant, Pale bluish purple } \\
(19-17-4)\end{array}$ & Yellowish brown (17-16-4) & None \\
\hline $\begin{array}{l}\text { Inorganic salts - starch agar } \\
\text { (ISP No. 4) }\end{array}$ & Good & $\begin{array}{l}\text { Abundant, Pale bluish purple } \\
(19-18-3)\end{array}$ & Yellowish brown (7-16-3) & None \\
\hline $\begin{array}{l}\text { Glycerol - asparagine agar } \\
\text { (ISP No. 5) }\end{array}$ & Good & $\begin{array}{l}\text { Abundant, Grayish purple } \\
(20-17-2)\end{array}$ & $\begin{array}{l}\text { Pale yellowish brown } \\
(7-18-2)\end{array}$ & None \\
\hline $\begin{array}{l}\text { Peptone - yeast extract iron } \\
\text { agar (ISP No. 6) }\end{array}$ & Poor & None & $\begin{array}{l}\text { Dark yellowish brown } \\
(7-13-2)\end{array}$ & None \\
\hline Tyrosine agar (ISP No. 7) & Good & $\begin{array}{l}\text { Abundant, Pale purple } \\
\quad(20-18-2)\end{array}$ & Yellowish brown (7-16-3) & None \\
\hline BENNETT's agar & Good & $\begin{array}{l}\text { Abundant, Pale purple } \\
\quad(20-18-2)\end{array}$ & Yellowish brown (7-16-3) & None \\
\hline
\end{tabular}

* Color codes from the Guide to Color Standard.

Fig. 1. Scanning electron micrograph of producing strain, Streptomyces sp. AS1345.

Bar represents $2 \mu \mathrm{m}$.

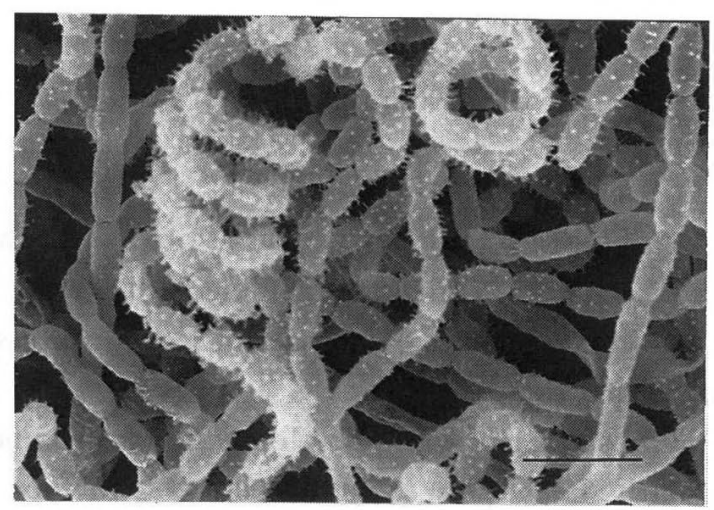

$0.5 \%$ Soytone, $0.2 \%$ yeast extract, $0.5 \%$ corn steep liquor, and $0.3 \% \mathrm{CaCO}_{3}$, adjusted at $\mathrm{pH} 6.5$ before autoclaving, and incubated for 6 days at $27{ }^{\circ} \mathrm{C}$ on a rotary shaker $(220 \mathrm{rpm})$. One milliliter of the seed culture was transferred to a 500-ml Erlenmeyer flask containing $70 \mathrm{ml}$ of a production medium composed of $0.5 \%$ glucose, $2.0 \%$ dextrin, $2.0 \%$ glycerol, $1.5 \%$ rape-seed meal, $0.5 \%$ corn steep liquor, $0.2 \%$ yeast extract, $0.3 \%$ $\mathrm{CaCO}_{3}$, and $0.2 \%$ Polypeptone, adjusted at $\mathrm{pH} 7.0$ before autoclaving, and incubated for 5 days at $27^{\circ} \mathrm{C}$ on a rotary shaker $(220 \mathrm{rpm})$.

\section{Isolation}

The culture broth (7 liters) of one hundred flasks was
Table 2. Physiological properties of strain AS1345.

\begin{tabular}{lc}
\hline Temperature range for growth & $10 \sim 37^{\circ} \mathrm{C}$ \\
Optimum temperature for growth & $27 \sim 30^{\circ} \mathrm{C}$ \\
Production of melanoid pigment & \\
ISP No. 6 & + \\
ISP No. 7 & + \\
Hydrolysis of starch & - \\
Decomposition of cellulose & + \\
Reduction of nitrate & $6 \%$ \\
NaCl tolerance & \\
Utilization of carbon source & + \\
L-Arabinose & + \\
D-Fructose & + \\
D-Glucose & \pm \\
Inositol & - \\
D-Mannitol & + \\
Raffinose & - \\
L-Rhamnose & - \\
Sucrose & + \\
D-Xylose & \\
\hline
\end{tabular}

+ , Positive; \pm , doubtful; - , negative.

extracted with ethylacetate and then concentrated in vacuo. The extract was subjected to a reverse-phase silica gel (YMC ODS A60) column chromatography, followed by gradient elution with $\mathrm{CH}_{3} \mathrm{CN}-\mathrm{H}_{2} \mathrm{O}$ from $4: 6$ to $5: 5$. The fractions containing TMC-49A were identified by the reporter assay to test the effect on the transcription of LDL receptor gene. The active fractions were concentrated and further purified by Sephadex LH-20 column chromatography with $\mathrm{CH}_{2} \mathrm{Cl}_{2}-\mathrm{MeOH}$ (1:1). After 
concentration of the active fractions, purified TMC-49A was obtained as colorless oil (480 mg).

\section{Physico-chemical Properties}

Physico-chemical properties of TMC-49A are summarized in Table 3. The molecular formula of TMC49A was established as $\mathrm{C}_{13} \mathrm{H}_{19} \mathrm{NO}_{2}$ by high-resolution FAB-MS and NMR data. IR absorptions at 1700, 1530, and $1250 \mathrm{~cm}^{-1}$ implied the presence of a carbamate group.

\section{Structure Elucidation}

The ${ }^{13} \mathrm{C}$ NMR and ${ }^{1} \mathrm{H}$ NMR spectral data are summarized in Table 4 . The data indicated the presence of a methyl, five methines, a ketone, and a monosubstituted benzene ring. Based on the results of $1 \mathrm{D}$ and $2 \mathrm{D}$ NMR $\left({ }^{1} \mathrm{H}-{ }^{1} \mathrm{H}\right.$ COSY and ${ }^{13} \mathrm{C}-{ }^{1} \mathrm{H}$ long range COSY) (Fig. 2), the structure of TMC-49A was determined to be butyl $N$-phenethylcarbamate. High-resolution FABMS spectrum supported this structure (Fig. 2).

Table 3. Physico-chemical properties of TMC-49A.

\begin{tabular}{ll}
\hline Appearance & Colorless oil \\
BP $\left({ }^{\circ} \mathrm{C}\right)$ & $120 \sim 122$ \\
Molecular formula & $\mathrm{C}_{13} \mathrm{H}_{19} \mathrm{NO}_{2}$ \\
HRFAB-MS $(\mathrm{m} / z)$ & \\
$\quad$ Found & $222.1491(\mathrm{M}+\mathrm{H})^{+}$ \\
Calcd & 222.1494 \\
$\mathrm{UV} \lambda_{\max }(\mathrm{MeOH}) \mathrm{nm}(\varepsilon)$ & $260(270)$ \\
$\mathrm{IR} v_{\max }(\mathrm{KBr}) \mathrm{cm}^{-1}$ & $3325,2950,1700,1530$ \\
& 1250 \\
Solubility & Soluble in $\mathrm{MeOH}^{+}$ \\
& EtOAc, DMSO, CHCl \\
& Insoluble in $\mathrm{H}_{2} \mathrm{O}$, \\
& Acetone \\
\hline
\end{tabular}

\section{Biological Properties}

The effect on the transcription of LDL receptor gene was assessed by a reporter assay using the recombinant cells that expressed luciferase activity under the control of LDL receptor promoter. The expression of lucifease

Table 4. ${ }^{1} \mathrm{H}$ and ${ }^{13} \mathrm{C}$ NMR data of TMC-49A in $\mathrm{CDCl}_{3}$.

\begin{tabular}{crl}
\hline Position & ${ }^{13} \mathrm{C}\left(\delta_{\mathrm{C}}\right)$ & \multicolumn{1}{c}{${ }^{1} \mathrm{H}\left(\delta_{\mathrm{H}}\right)$} \\
\hline 1 & $156.7(\mathrm{~s})$ & \\
2 & & $4.65(\mathrm{br})$ \\
3 & $42.1(\mathrm{t})$ & $3.42(2 \mathrm{H}, \mathrm{m})$ \\
4 & $36.2(\mathrm{t})$ & $2.80(2 \mathrm{H}, \mathrm{t}, J=6.99 \mathrm{~Hz})$ \\
5 & $138.8(\mathrm{~s})$ & \\
6,10 & $128.8(\mathrm{~d})$ & $7.29(2 \mathrm{H}, \mathrm{m})$ \\
7,9 & $128.6(\mathrm{~d})$ & $7.18(2 \mathrm{H}, \mathrm{m})$ \\
8 & $126.5(\mathrm{~d})$ & $7.25(1 \mathrm{H}, \mathrm{m})$ \\
11 & $64.7(\mathrm{t})$ & $4.05(2 \mathrm{H}, \mathrm{t}, J=6.72 \mathrm{~Hz})$ \\
12 & $31.1(\mathrm{t})$ & $1.58(2 \mathrm{H}, \mathrm{m})$ \\
13 & $19.1(\mathrm{t})$ & $1.36(2 \mathrm{H}, \mathrm{m})$ \\
14 & $13.7(\mathrm{q})$ & $0.92(3 \mathrm{H}, \mathrm{t}, J=7.39 \mathrm{~Hz})$ \\
\hline
\end{tabular}

Fig. 2. Structure of TMC-49A.

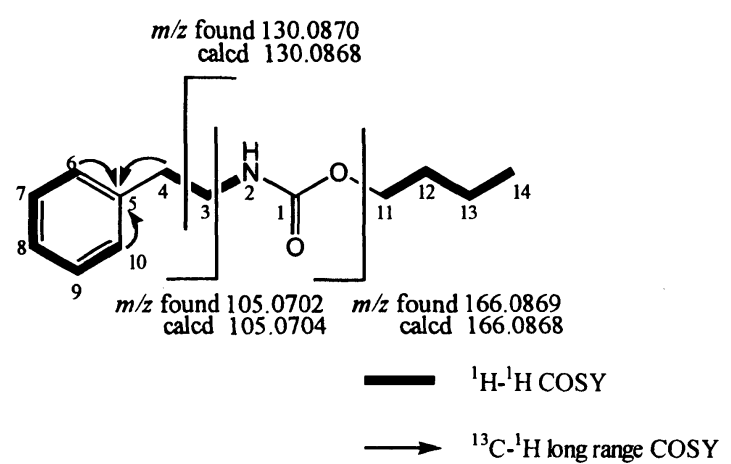

Table 5. Effect of TMC-49A on the expression of luciferase activity under the control of LDL receptor promoter in the transfected $\mathrm{CHO}$ cells and on specific binding of ${ }^{125} \mathrm{I}-\mathrm{LDL}$ to LDL receptor in HepG2 cells.

\begin{tabular}{cccc}
\hline Compound & $\begin{array}{c}\text { Concentration } \\
(\mu \mathrm{M})\end{array}$ & $\begin{array}{c}\text { Luciferase activity } \\
\left.(\% \text { of control })^{\mathrm{a}}\right)\end{array}$ & $\begin{array}{c}\text { Specific binding } \\
\left(\% \text { of control }^{\mathrm{b}}\right)\end{array}$ \\
\hline TMC-49A & 50 & 1519 & $-\mathbf{c}^{\mathrm{c}}$ \\
& 10 & 392 & 185 \\
Lovastatin & 2 & 158 & 117 \\
\hline
\end{tabular}

a A control was the luciferase activity expressed in the recombinantCHO cells cultured in the absence of test compounds.

b A control was the specific binding of ${ }^{125} \mathrm{I}-\mathrm{LDL}$ to the LDL receptors of HepG2 cells cultured in the absence of test compounds.

c - Not determined. 
activity in the cells was suppressed or activated by supplementation to culture medium of LDL or lovasatin, an HMG-CoA inhibitor, respectively (data not shown). As shown in Table 5, the expression of luciferase activity was enhanced by TMC-49A in a dose-dependent manner.

To investigate the effect of TMC-49A on the synthesis of LDL receptor, we carried out the receptor binding assay by using human hepatoma HepG2 cells and ${ }^{125} \mathrm{I}-\mathrm{LDL}$ as a ligand. When the cells were cultured in the presence of $2 \mu \mathrm{M}$ TMC-49A, the specific binding of ${ }^{125} \mathrm{I}-\mathrm{LDL}$ was increased by $85 \%$, taking the specific binding of cells cultured without test compounds as $100 \%$ (Table 5).

\section{Discussion}

In this study, TMC-49A was discovered as the novel transcriptional up-regulator of LDL receptor gene from the culture broth of Streptomyces sp. AS1345. The structure of TMC-49A was determined to be butyl $N$-phenethylcarbamate by the spectroscopic analyses. This is the first report on isolation of the compound with this structure from the nature, although the structure is simple. TMC-49A was confirmed to enhance the synthesis of LDL receptor in HepG2 cells. TMC-49A is a new chemical entity and a transcriptional activator of LDL receptor, that does not share a common structure with the previously reported activators, trichostatin $\mathrm{A}^{7)}$, herboxidiene $^{7)}$, macrolide antibiotics ${ }^{8)}$, chenodeoxycholic acid $^{9)}$, and $N$-acetyl-leucyl-leucyl-norleucinal ${ }^{10)}$.

The mechanism of the activation by TMC-49A has not been clarified, but it would differ from that of lovastatin since TMC-49A did not inhibit cholesterol biosynthesis (data not shown). Further study will address to the activation mechanism and give information on the regulation of $\mathrm{LDL}$ receptor synthesis.

TMC-49A was not so effective for the transcriptional up-regulation of LDL receptor as trichostatin $A$ and herboxidiene ${ }^{7)}$. However, because of the simple structure of TMC-49A, it would be relatively easy to identify the moieties essential for the activation and to synthesize chemically its derivatives with higher potencies. TMC49A has another advantage that it exhibited low cytotoxicity as compared to trichostatin $\mathrm{A}$ and herboxidiene. Chemical derivation of TMC-49A will be reported in near future.

\section{Experimental}

General

${ }^{1} \mathrm{H}$ and ${ }^{13} \mathrm{C}$ NMR spectra were recorded with a JEOL GSX-400 NMR spectrometer by using sodium 3-(trimethylsilyl)-1-propanesulfonate as an internal standard. Mass spectrum was obtained with a JEOL JMS HX-411 spectrometer. UV and IR spectra were measured with a Shimadzu model UV-2200A spectrometer and a JASCO model 100 infrared spectrophotometer, respectively.

\section{Taxonomic Studies}

Cultural and physiological characteristics were determined by the methods of SHIRLING and GotTLIEB ${ }^{11)}$. Carbohydrate utilization was investigated by using the procedure of PRIDHAM and GotTLIEB ${ }^{12)}$. The substrate and aerial mass color were assigned by Guide to Color Standard, 1954 (Japan Color Research Institute). Morphological characteristics were observed with a scanning electron microscope (Hitachi S-4200). 2,6-Diaminopimelic acid in the whole cells was analyzed according to the method of BECKER et al. ${ }^{13)}$ and the method of HASEGAWA et al. ${ }^{14)}$.

\section{Reporter Assay and LDL Binding Assay}

The reporter assay was carried out by using the $\mathrm{CHO}$ cells, which expressed luciferase activity under the control of the promoter of $\mathrm{LDL}$ receptor gene, as described previously ${ }^{7)}$. Amounts of LDL receptor synthesized in human hepatoma HepG2 cells were measured by the receptor binding assay using the whole cells and ${ }^{125} \mathrm{I}-\mathrm{LDL}$ as a ligand ${ }^{7)}$.

\section{Acknowledgments}

We thank Mr. Jun Kotera for the LDL binding assay. We also thank Dr. Tetsuya Tosa and Dr. Keisuke Kawashima for their encouragement.

\section{References}

1) Brown, M. S. \& J. L. Goldstein: A receptor-mediated pathway for cholesterol homeostasis. Science 232: 34 47, 1986

2) Briggs, M. R.; C. Yokoyama, X. Wang, M. S. Brown \& J. L. GoldSTEIN: Nuclear protein that binds sterol regulatory element of low density lipoprotein receptor promoter. I. Identification of the protein and delineation of its target nucleotide sequence. J. Biol. Chem. 268: $14490 \sim 14496,1993$

3) Wang, X.; M. R. Briggs, X. Hua, C. Yokoyama, J. L. GOLDSTEIN \& M. S. BROWN: Nuclear protein that binds sterol regulatory element of low density lipoprotein receptor promoter. II. Purification and characterization. J. Biol. Chem. 268: 14497 14504, 1993 
4) Mabuchi, H.; N. Kamon, H. Fujita, I. Michishita, M. TAKeda, K. KaJinami, H. Itho, T. WaKasugi \& R. TAKEDA: Effect of CS-514 on serum lipoprotein and apolipoprotein levels in patients with familial hypercholesterolemia. Metabolism 36: 475 479, 1987

5) Tsuji, N.; M. Kobayashi, K. Nagashima, Y. Wakisaka \& K. KoIzumI: A new antifungal antibiotic, trichosatain. J. Antibiotics 29: 1 6, 1976

6) Wideman, M. M.; N. Makkar, M. Tran, B. Isaac, N. Biest \& R. STONARD: Herboxidiene, a new herbicidal substance from Streptomyces chromofuscus A7847. J. Antibiotics 45: 914 921, 1992

7) Koguchi, Y.; M. Nishio, J. Kotera, K. Omori, T. OHNUKI \& S. Komatsubara: Trichostatin A and herboxidiene up-regulate the gene expression of low density lipoprotein receptor. J. Antibiotics 50: 970 971, 1997

8) Ogasawara, M.; N. Naruse, A. Yoshimura, Y. HAMAGISHI \& T. OKI: Elevation of low density lipoprotein-receptor mRNA concentration in human hepatoma HepG2 cells by macrolide antibiotics. J. Antibiotics 46: 866 868, 1993

9) Kawabe, Y.; T. Shimokawa, A. Matsumoto, M. Honda,
Y. Wada, Y. Yazaki, A. Endo, H. Itakura \& T. KODAMA: The molecular mechanism of the induction of low density lipoprotein receptor by chenodeoxycholic acid in cultured human cells. Biochem. Biophys. Res. Comm. 208: $405 \sim 411,1995$

10) WANG, X.; R. Sato, M. S. Brown, X. Hua \& J. L. GOLDSTEIN: SREBP-1, a membrane-bound transcription factor released by sterol-regulated proteolysis. Cell 77: $53 \sim 62,1994$

11) Shirling, E. B. \& D. Gottlieb: Methods for characterization of Streptomyces species. Int. J. Syst. Bacteriol. 16: 313 340, 1966

12) Pridham, T. G. \& D. Gottlieb: The utilization of carbon compounds by some Actinomycetales as an aid for species determination. J. Bacteriol. 56: $107 \sim 114,1948$

13) Becker, B.; M. P. LeChevalier, R. E. Gordon \& H. A. LECHEVALIER: Rapid differentiation between Nocardia and Streptomyces by paper chromatography of whole cell hydrolysates. Appl. Microbiol. 12: $421 \sim 423,1964$

14) Hasegawa, T.; M. Takizawa \& S. Tanida: A rapid analysis for chemical grouping of aerobic actinomycetes. J. Gen. Appl. Microbiol. 29: 319 322, 1983 